\section{Television viewing and abdominal obesity in women according to smoking status: results from a large cross- sectional population-based study in Brazil}

\section{Hábito de assistir televisão e obesidade abdominal entre mulheres fumantes: resultados de um estudo transversal de base populacional no Brasil}

\author{
Taísa Rodrigues Cortes' \\ Michael Maia Schlussel" \\ Ana Beatriz Franco-Sena" \\ Fernanda Rebelo" \\ Gilberto Kac ${ }^{\prime \prime}$, II \\ 'Graduate Program in Epidemiology, Rio de Janeiro State University, Rio de \\ Janeiro, Brazil. \\ "Graduate Program in Nutrition, Institute of Nutrition Josué de Castro, Federal \\ University of Rio de Janeiro, Rio de Janeiro, Brazil. \\ "'Department of Social and Applied Nutrition, Institute of Nutrition Josué de \\ Castro, Federal University of Rio de Janeiro, Rio de Janeiro, Brazil.
}

Corresponding author: Gilberto Kac. Departamento de Nutrição Social e Aplicada do Instituto de Nutrição Josué de Castro da Universidade Federal do Rio de Janeiro - UFRJ. Avenida Carlos Chagas Filho, 367 - CCS - Bloco J - 2 andar, sala 29, Cidade Universitária - 21941-902 Ilha do Fundão, Rio de Janeiro, RJ, BRAZIL. E-mail: gilberto.kac@gmail.com

\section{Abstract}

Objective: To investigate the associations between television viewing and abdominal obesity (AO) in Brazilian women, according to smoking status. Methods: Data of 13,262 adult women (18-49 years) from the 2006's Demographic Health Survey, a cross-sectional household study with complex probabilistic sample and national representativeness, were analyzed. $\mathrm{AO}$, defined as waist circumference $\geq 80.0 \mathrm{~cm}$, was the outcome. Television viewing frequency ( $\geq 5$ times/week, 1-4 times/week, $<1$ time/ week) was the main exposure variable, and smoking status (yes or no) the main covariable. Prevalence ratios were estimated using Poisson regression models separately for smokers and non-smokers. Results: A statistically significant interaction term was observed between smoking status and television viewing $(\mathrm{p}<0.05)$. Prevalence of AO among smokers who reported television viewing $\geq 5$ times/week amounted to $59.0 \%$, higher than the $35.0 \%$ for those with $<1$ time/week television viewing ( $\mathrm{p}$-value $=0.020$ ). The values for non-smokers were $55.2 \%$ and $55.7 \%$, respectively. Smokers with television viewing $\geq 5$ times/week were 1.7 times (95\% CI: 1.1-2.5) more likely to present $\mathrm{AO}$, compared to those who reported a frequency $<1$ time/week. There was no significant association among non-smokers. Conclusions: Television viewing $\geq 5$ times/ week may increase the prevalence of $\mathrm{AO}$ among women who smoke. More detailed information on media use, as hours per day, may offer better estimates.

Keywords: Waist circumference. Abdominal obesity. Television. Smoking. Populationbased study. Women's health. 


\section{Resumo}

Objetivo: Investigar a associação entre a frequência assistindo televisão e obesidade abdominal (OA) entre mulheres brasileiras, segundo o hábito de fumar. Métodos: Foram analisados os dados de 13.262 mulheres adultas (18-49 anos) estudadas na Pesquisa Nacional de Demografia e Saúde (PNDS-2006), um estudo transversal, com amostragem probabilística complexa, de representatividade nacional. OA, definida como circunferência da cintura $\geq 80.0 \mathrm{~cm}$, foi considerada como desfecho. A frequência assistindo televisão ( $\geq 5$ vezes/semana, 1-4 vezes/semana, < 1 vez/semana) foi a principal variável de exposição e o hábito de fumar (sim ou não) a principal covariável. Foram estimadas razões de prevalência por meio de modelos de regressão de Poisson, para fumantes e não fumantes separadamente. Resultados: Observou-se interação estatisticamente significante entre frequência assistindo televisão e hábito de fumar ( $\mathrm{p}$ $<0,05$ ). A prevalência de OA entre mulheres fumantes que assistiam televisão $\geq 5$ vezes/ semana foi de $59,0 \%$, e maior do que $35,0 \%$ entre aquelas que assistiam televisão $<1$ vez/semana $(p$-valor $=0,02)$. Os valores de OA para não fumantes foram $55,2 \%$ e $55,7 \%$, respectivamente. Fumantes que assistiam televisão $\geq 5$ vezes/semana apresentaram chance $1,7(1,1-2,5)$ vezes maior de ter OA comparadas aquelas que relataram assistir televisão < 1 vez/semana. Não se observou associação significante para não fumantes. Conclusão: Assistir televisão $\geq 5$ vezes/semana pode aumentar a prevalência de $\mathrm{OA}$ entre as mulheres fumantes. Informações mais detalhadas sobre a frequência de assistir televisão, como o número de horas por dia, podem oferecer melhores estimativas.

Palavras-chave: Circunferência da cintura. Obesidade abdominal. Televisão. Tabagismo. Estudo de base populacional. Saúde da mulher.

\section{Introduction}

The World Health Organization (WHO) recognizes obesity as a global epidemic ${ }^{1}$. In Brazil, the increase in prevalence of overweight and obesity in the population has been associated primarily with the nutritional transition, characterized by an increase in the consumption of refined carbohydrates and saturated and trans fats, and a reduction in the intake of complex carbohydrates, fibers, and polyunsaturated fats ${ }^{2}$.

Reduction in energy expenditure is considered one important determinant of the obesity epidemic ${ }^{3}$. Time spent watching television is the most investigated sedentary practice and some studies have reported a positive association between television viewing, overweight and obesity ${ }^{4-6}$. The probable explanation consists in the decrease in expenditure and increase in energy intake during time spent on television viewing?

Television viewing is a leisure activity accessible to all. According to the Pesquisa Nacional por Amostra de Domicílios (PNAD - National Household Sample Survey), the proportion of Brazilian households with television was $94.5 \%$ in $2007^{8}$. In this same year, in the United States, watching television was the most frequent leisure activity, occupying approximately three hours per day $^{9}$.

Smokers frequently present lower BMI when compared to non-smokers ${ }^{10-12}$, although smoking may favor abdominal obesity (AO) accumulation ${ }^{13-15}$. Smoking and $\mathrm{AO}$ are primary risk factors for several chronic disease ${ }^{16-17}$ and the presence of these two conditions simultaneously leads to an increase in the risk for unfavorable outcomes $^{18-19}$. The conceptual framework of the present study is based on the assumption that an increased number of smoked cigarettes is positively associated with a higher television viewing frequency, which in turn is associated with increased risk of $\mathrm{AO}^{20}$.

To our knowledge, no populationbased studies have considered the habit of 
smoking as a modifier of the relationship between television viewing and AO. In this regard, the present study undertook as its objective to investigate the association between television viewing frequency and $\mathrm{AO}$ among smoking and non-smoking Brazilian women aged 18-49 years.

\section{Methods}

The data were derived from the third edition of the Demographic Health Survey (DHS), conducted in 2006-07, in Brazil. This was a population-based household survey targeting women of reproductive age, including mothers of children younger than five years of age. DHS was a nationally representative cross-sectional study with a complex sampling design. Ten sampling strata were defined, based on a combination of the five Brazilian geographical regions and urban $v$ s. rural areas. The respondents' sampling weights were derived from the household sampling weights and took into account the possibility that there may be more than one eligible woman in each household. The weights were adjusted due to non-response within households and were calibrated based on official population estimates released by the Instituto Brasileiro de Geografia e Estatística (IBGE - Brazilian Institute of Geography and Statistics).

Data from 15,575 women living in 13,056 households were collected, including information from households that contained at least one eligible woman. For the present analysis, data from 13,262 adult women aged 18-49 years, who were not pregnant at the time of the interview and with available waist circumference (WC) measurements, were considered. Structured questionnaires were applied through in-person interviews and anthropometric measures were taken. Data collected included socioeconomic status, lifestyle and reproductive history.

$\mathrm{AO}$ was evaluated using WC measurements $(\mathrm{cm})$ collected according to WHO recommendations. WC was measured twice at the point between the last rib and the iliac crest with an inelastic measuring tape. The mean value was used as the final estimation. Subjects were classified in two categories: $\mathrm{WC}<80 \mathrm{~cm}$ (adequate); $\mathrm{WC} \geq 80.0 \mathrm{~cm}(\mathrm{AO})^{21}$.

The frequency of television viewing was considered the main exposure variable and was collected through the question "do you usually watch television?" Originally, the following frequency options were available: everyday, almost every day, at least once a week, less than once a month, and does not watch. According to the original categories, $80 \%$ of women watched TV every day, $10 \%$ almost every day, $5 \%$ at least once a week, $1 \%$ less than once a month and $4 \%$ did not watch TV. Participants were regrouped into the following categories of television frequency, aiming to avoid categories with a small number of subjects: $\geq 5$ times/week (90\%), 1-4 times/week (5\%) and $<1$ time/ week $(5 \%)$.

The main co-variable was smoking habit; assessed through the question "do you currently smoke?" Individuals were classified as smokers and non-smokers. The other co-variables were included in the analysis aiming to control confounding in the relationship between television viewing, smoking, and AO: age group (18-19, 20-29, 30-39, 40-49 years), ethnicity (white, black, mixed and others), parity (zero, 1, 2, $\geq 3$ children), marital status (married, cohabiting, not cohabiting), family income (quartiles), and geographical region (North, Northeast, Southeast, South, Midwest).

Statistical analyses were conducted considering the complex sample design. Initially, the samples' characteristics were described according to $\mathrm{WC}(\geq 80 /<80 \mathrm{~cm})$ with proportion distributions and Chisquare tests. Next, the prevalences of $\mathrm{AO}$ with $95 \%$ confidence intervals were calculated according to the frequency of television viewing. Finally, crude and adjusted Prevalence Ratios (PR) with 95\% confidence intervals were calculated using Poisson regression models, having $\mathrm{AO}$ as the dependent variable and television viewing as the main exposure. $\mathrm{WC}<80 \mathrm{~cm}$ was considered the reference category. All analyses on the association between television viewing and 
$\mathrm{AO}$ were conducted separately for smokers and non-smokers, because a statistically significant interaction effect on the prevalence of $\mathrm{AO}$ was found between television viewing and smoking status. Analyses were performed using the STATA 9.2 software.

\section{Results}

Women with AO were more likely to belong to older age groups, to be married and to have three or more children. Approximately $90 \%$ of women watched television $\geq 5$ times/ week. The overall prevalence of AO amounted to $55 \%$ (Table 1). Non-smoker women were younger and had lower parity when compared with smoking women. Comparisons between smokers and non-smokers revealed significant differences in geographical region and marital status (results not shown).

The prevalence of $\mathrm{AO}$ amounted to $59 \%$ among smoking women with the highest frequency of television viewing when compared to $35 \%$ for those with < 1 time/ week ( $p$-value $=0.020$ ). Among non-smoking women, there was only a slight difference in the prevalence of $\mathrm{AO}$ when comparing frequencies of television viewing $(55.2 \%$ vs. $55.7 \%$, p-value $=0.189$ ) (Table 2).

Prevalence ratios showed that $\mathrm{AO}$ among smokers was 1.7 (95\%CI: 1.1-2.5) times more frequent for women with a television viewing frequency $\geq 5$ times/week, when compared to smoking women with a frequency $<1$ times/week. The results were adjusted for age, parity, ethnicity, and marital status. The relationship between television viewing frequency and $\mathrm{AO}$ was not significant among non-smoking women (PR=1.1; 95\%CI: 0.9-1.2) (Table 3).

\section{Discussion}

The results of the present investigation revealed an interaction between television viewing and smoking status in a sample of Brazilian women aged 18-49 years, the reason why the multiple adjusted Poisson regression models were stratified according to smoking status. Among smokers, television viewing five or more times per week represented an increase of $70 \%$ in the prevalence of $\mathrm{AO}$, in comparison with smokers who reported watching television less than once a week. These results remained significant in the adjusted analysis, when confounding factors such as age, ethnicity, parity, and marital status were controlled. Among non-smokers, the prevalence ratio of obesity for those with a television viewing frequency of five or more times per week (1.1; 95\% CI: 0.9-1.2), in comparison to those who reported watching television less than once a week, was not statically significant. It is important to note, however, that despite the lower prevalence of $\mathrm{AO}$ among smokers who watched television less than once a week, the prevalence of $\mathrm{AO}$ was high and almost identical among those with the highest television viewing frequency, independently of the smoking status.

To our knowledge, no study has considered the effect of modification of smoking on media use frequency, including the amount of time of daily television viewing and AO. The present discussion is based on a hypothesis that follows a previously established conceptual framework. The first part considers the relationship among smoking intensity, television exposure and a higher likelihood of developing $\mathrm{AO}$, which might explain how smoking is capable of modifying the effect of media exposure on AO. The second part relies on studies which revealed that smokers had a lower qualitative dietary intake, fewer healthy habits, and an increased risk for central obesity ${ }^{22,23}$, when compared to non-smokers.

A recent study revealed that excessive television exposure and smoking intensity were positively related, meaning that more television exposure is associated to more smoking ${ }^{20}$. Although the relationship between smoking status and television viewing frequency is not well understood, the results of this study are useful to document this relationship. Following this idea, smoking would modify television frequency, a life style habit, and consequently increase the risk of AO. 
Table 1 - Characteristics of the women studied according to waist circumference (WC) - National Survey of Women and Child Demography and Health' (2006)

Tabela 1 - Características das mulheres estudadas, segundo circunferência da cintura (CC) - Pesquisa Nacional de Demografia e Saúde da Criança e da Mulher' (2006).

\begin{tabular}{|c|c|c|c|}
\hline \multirow{2}{*}{ Variables } & $W C<80 \mathrm{~cm}$ & $W C \geq 80.0 \mathrm{~cm}$ & Total \\
\hline & $\%[95 \% \mathrm{Cl}]$ & $\%[95 \% \mathrm{Cl}]$ & $\%[95 \% \mathrm{Cl}]$ \\
\hline Age (years) & $\mathrm{n}=5919$ & $n=7343$ & $n=13262$ \\
\hline 18-19 & $12[11-14]$ & $04[03-05]$ & 08 [07-09] \\
\hline $20-29$ & $45[43-47]$ & $25[24-27]$ & 34 [33-36] \\
\hline $30-39$ & $26[24-27]$ & $34[33-36]$ & $30[29-22]$ \\
\hline $40-49$ & 17 [16-19] & 37 [35-39] & 28 [27-29] \\
\hline Ethnicity ${ }^{2}$ & $\mathrm{n}=5856$ & $\mathrm{n}=7284$ & $\mathrm{n}=13140$ \\
\hline White & $41[38-44]$ & $40[38-43]$ & 41 [39-43] \\
\hline Black & $09[08-11]$ & $12[10-13]$ & 10 [09-12] \\
\hline Mixed & $44[41-47]$ & $44[41-46]$ & $44[42-46]$ \\
\hline Others & $06[05-08]$ & 04 [03-05] & 05 [04-06] \\
\hline Parity (number of children) & $\mathrm{n}=5919$ & $n=7343$ & $\mathrm{n}=13262$ \\
\hline Zero & $40[37-42]$ & $18[16-20]$ & 28 [26-29] \\
\hline 1 & $24[22-26]$ & $22[21-24]$ & $23[22-25]$ \\
\hline 2 & $21[20-23]$ & $29[27-31]$ & 25 [24-27] \\
\hline$\geq 3$ & $15[14-17]$ & 31 [29-33] & $24[23-25]$ \\
\hline Marital status $^{2}$ & $n=5913$ & $n=7337$ & $\mathrm{n}=13250$ \\
\hline Married & $32[30-34]$ & 47 [44-49] & $40[38-42]$ \\
\hline Cohabiting & $27[25-29]$ & $29[27-31]$ & $28[26-30]$ \\
\hline Not cohabiting & $41[39-44]$ & $24[22-26]$ & $32[30-34]$ \\
\hline Family income (in Brazilian reais, quartiles) ${ }^{3}$ & $\mathrm{n}=4622$ & $\mathrm{n}=5981$ & $\mathrm{n}=10603$ \\
\hline$\leq 350\left(1^{\text {st }}\right)$ & $22[20-25]$ & $23[21-25]$ & $23[21-24]$ \\
\hline $351-700\left(2^{\text {nd }}\right)$ & $25[22-27]$ & $24[22-26]$ & $24[23-26]$ \\
\hline $701-1400\left(3^{\text {rd }}\right)$ & $25[23-27]$ & $27[25-29]$ & $26[24-28]$ \\
\hline$>1400\left(4^{\text {th }}\right)$ & $28[25-31]$ & 26 [24-29] & 27 [25-29] \\
\hline Geographical region & $\mathrm{n}=5919$ & $n=7343$ & $n=13262$ \\
\hline North & 08 [07-09] & 07 [06-08] & 07 [07-08] \\
\hline Northeast & $25[23-28]$ & 27 [24-29] & 26 [24-28] \\
\hline Southeast & $43[40-46]$ & $44[42-47]$ & $44[42-46]$ \\
\hline South & 16 [15-18] & 15 [13-16] & 15 [14-16] \\
\hline Midwest & 08 [07-09] & 07 [07-08] & 07 [07-08] \\
\hline Television viewing frequency ${ }^{2}$ (times per week) & $n=5915$ & $n=7340$ & $\mathrm{n}=13255$ \\
\hline$\geq 5$ & $89[88-91]$ & $91[90-92]$ & 90 [89-91] \\
\hline $1-4$ & $06[05-07]$ & $05[04-06]$ & 05 [05-06] \\
\hline$<1$ & $05[04-06]$ & 04 [04-05] & 05 [05-09] \\
\hline Smoking habit & $\mathrm{n}=5919$ & $n=7343$ & $\mathrm{n}=13262$ \\
\hline Non-smoker & $85[84-87]$ & $84[82-85]$ & $85[83-86]$ \\
\hline Smoker & $15[13-16]$ & $16[15-18]$ & 15 [14-17] \\
\hline
\end{tabular}

1. Data refer to non-pregnant 18-49 year old women. 2. Variables with losses lower than 1\%. 3. Variable with losses higher than $20 \%$. Notes: Estimates were weighted and standard error was corrected to take into account the complex sampling design. Chi-square tests were significant $(p<0.01)$ for age category, ethnicity, parity and marital status.

1. Os dados se referem a mulheres não grávidas com idade entre 18 e 49 anos. 2. Variáveis com perda inferior a 1\%. 3. Variável com perda superior a 20\%. Notas: As estimativas foram ponderadas e o erro padrão corrigido para considerar o desenho amostral complexo. Os testes chi-quadrado foram significantes $(p<0,01)$ para a faixa etária; cor de pele; paridade; estado marital. 
Table 2 - Prevalence and confidence intervals $(95 \% \mathrm{Cl})$ of waist circumference (WC) categories according to the television viewing frequency and smoking status - National Survey of Women's and Child Demography and Health' (2006).

Tabela 2 - Prevalência e intervalos de confiança (IC 95\%) de categorias de circunferência da cintura (CC) segundo frequência assistindo televisão e hábito de fumar - Pesquisa Nacional de Demografia e Saúde da Criança e da Mulher'(2006).

\begin{tabular}{|c|c|c|c|c|c|c|c|c|}
\hline \multirow{3}{*}{$\begin{array}{l}\text { Television } \\
\text { viewing } \\
\text { frequency } \\
\text { (times/week) }\end{array}$} & \multicolumn{4}{|c|}{ Non-smokers } & \multicolumn{4}{|c|}{ Smokers } \\
\hline & & $W C<80.0 \mathrm{~cm}$ & $W C \geq 80.0 \mathrm{~cm}$ & & & $W C<80.0 \mathrm{~cm}$ & $W C \geq 80.0 \mathrm{~cm}$ & \\
\hline & $n$ & $\begin{array}{c}\text { Prevalence } \\
{[95 \% \mathrm{Cl}]}\end{array}$ & $\begin{array}{c}\text { Prevalence } \\
{[95 \% \mathrm{Cl}]}\end{array}$ & $p$ & $n$ & $\begin{array}{c}\text { Prevalence } \\
{[95 \% \mathrm{Cl}]}\end{array}$ & $\begin{array}{c}\text { Prevalence } \\
{[\mathrm{C} 95 \% \mathrm{Cl}]}\end{array}$ & $p$ \\
\hline$\geq 5$ & 10041 & 44.8 [42.9-46.8] & $55.2[53.2-57.1]$ & & 1811 & 41.0 [37.1-45.0] & 59.0 [55.0-62.9] & \\
\hline $1-4$ & 544 & 51.7 [43.9-59.4] & $48.3[40.6-56.1]$ & & 88 & 45.2 [29.9-61.4] & $54.8[38.5-70.1]$ & \\
\hline$<1$ & 670 & $44.3[37.7-51.1]$ & 55.7 [48.9-62.3] & & 101 & 65.0 [48.0-78.9] & 35.0 [21.1-52.0] & \\
\hline Total & 11255 & $45.2[43.4-47.0]$ & $54.8[53.0-56.6]$ & 0.189 & 2000 & 42.1 [38.3-45.9] & $57.9[54.1-61.7]$ & 0.020 \\
\hline
\end{tabular}

Notes: Estimates were weighted and standard error was corrected to take into account the complex sampling design. $\mathrm{P}$ values refer to Chi-square test for difference of proportions.

1. Data on this table refer to non-pregnant 18 to 49 -year-old women.

Notas: As estimativas são ponderadas e o erro padrão foi corrigido para considerar o desenho amostral complexo. O valor de p se refere ao teste Qui-quadrado para diferença de proporções.

1. Os dados desta tabela são referentes a mulheres não grávidas com idade de 18 a 49 anos.

Table 3 - Crude and adjusted prevalence ratio (PR) with confidence intervals $(95 \% \mathrm{Cl})$ of abdominal obesity according to television viewing frequency and smoking status - National Survey of Women's and Child Demography and Health' (2006).

Tabela 3 - Razão de prevalências bruta e ajustada e intervalos de confiança (IC 95\%) para obesidade abdominal, segundo frequência assistindo televisão e hábito de fumar - Pesquisa Nacional de Demografia e Saúde da Criança e da Mulher' (2006).

\begin{tabular}{lcccc}
\hline $\begin{array}{l}\text { Television viewing } \\
\text { frequency } \\
\text { (times/week) }\end{array}$ & $n$ & Crude PR [95\% Cl] & $n$ & Adjusted* PR [95\% Cl] \\
\cline { 2 - 5 } Non-smokers & 11255 & & 11139 & \\
$\geq 5$ & 10041 & $1.0[0.9-1.1]$ & 9937 & $1.1[0.9-1.2]$ \\
$1-4$ & 544 & $0.9[0.7-1.1]$ & 539 & $1.0[0.8-1.2]$ \\
$<1$ & 670 & 1.0 & 663 & 1.0 \\
Smokers & 2000 & & 1982 & \\
$\geq 5$ & 1811 & $1.7[1.1-2.7]$ & 1796 & $1.7[1.1-2.5]$ \\
$1-4$ & 88 & $1.6[0.9-2.7]$ & 86 & $1.5[0.9-2.5]$ \\
$<1$ & 101 & 1.0 & 100 & 1.0 \\
\hline
\end{tabular}

Note: Prevalence ratios (PR) were obtained by Poisson regression model. Estimates were weighted and standard error corrected to take into account the complex sampling design. 1. Data refer to non-pregnant 18 to 49 -year-old women. *Adjusted for age, parity, ethnicity, and marital status.

Nota: Razões de prevalência obtidas por meio de modelos de regressão de Poisson. As estimativas são ponderadas e o erro padrão foi corrigido para considerar o desenho amostral complexo. 1. Os dados desta tabela são referentes a mulheres não grávidas com idade de 18 a 49 anos. *Ajustado por idade, paridade, cor da pele e estado marital.

The positive association between television viewing and obesity is well documented in the literature ${ }^{24,25}$. Cleland et al. ${ }^{26}$ observed a greater prevalence of level-2 $\mathrm{AO}$ among Australian women who watched television for three hours a day, in comparison to those who watched only one hour a day. These results are in line with our study.

The second part of the potential explanation considers the associated life style habits that smokers tend to have. Smokers show a reduced consumption of fruits, vegetables, fibers, vitamins, and minerals ${ }^{23,27,28}$. Furthermore, smokers tend to consume 
more alcoholic beverages and coffee and practice less physical activities ${ }^{29}$. It is known that smoking and inadequate eating habits can be related to a tendency to be involved in other unhealthy behaviors ${ }^{30}$. The accumulation of these unhealthy habits is more likely to occur when the number of cigarettes smoked daily is greater ${ }^{31,32}$. Bowman et al. ${ }^{7}$ described that individuals who spend more time in front of the television have a greater energy intake and consume greater quantities of fat, protein, and carbohydrates, including added sugars.

Our results corroborate with some studies that have already described that smoking women tend to have greater central adiposity ${ }^{33}$. Troisi et al. ${ }^{13}$, confirmed the direct effect of smoking habit over the distribution of body fat, and verified that this relation was independent from other behavioral factors related to smoking, such as alcohol intake and physical activity. The evidences in regards to the biological mechanisms related to smoking and patterns of body fat distribution are still inconclusive ${ }^{34}$. Some results have indicated that abdominal fat accumulation is influenced by cortisol concentration. Smokers were shown to have higher cortisol levels compared to non-smokers ${ }^{35,36}$. Apart from that, Carney \& Goldberg ${ }^{37}$ described that the smoking habit may induce an increase in lipoprotein lipase activity, deregulating the uptake and storage of triglycerides and fatty acids by the adipocytes, consequently generating an increase in fat mass. In addition, evidences indicate that nicotine may have an antiestrogenic effect ${ }^{38}$.

One strength of this investigation is the fact of being a population-based study comprised of a representative sample of the Brazilian population of women aged 18-49 years, which is, therefore, an expressive sample size. Moreover, this study investigated an issue which is not well documented in the literature yet. However, it is also important to highlight some limitations. Ideally, the main co-variable of this study, television viewing frequency, should have been measured in terms of duration as minutes or at least hours per day, considering that approximately $90 \%$ of the sample watches television on a daily basis. A more sensitive measure of smoking, such as number of cigarettes per day, would have provided better estimates as well. These limitations could bias the results, although the potential direction of bias cannot be predicted. Other limitations include the lack of data on food consumption and physical activity, important determinants of AO.

From the perspective of public health, it is important to accumulate evidences of the negative effects of smoking and unhealthy habits, such as high television viewing frequency, on the distribution of body fat. It is important to draw the attention of international organizations to the lack of clear regulation for advertisements on television. It is known that the absence of a more explicit control exposes children, men, and women to an expressive number of unhealthy products.

\section{Conclusion}

Among women who smoke, watching television five or more times per week may increase the prevalence of AO in comparison with those that watched television less than once a week. Television viewing had no effect on $\mathrm{AO}$ prevalence among non-smokers.

Ethical approval: The State of São Paulo Department of Health Research Ethics Committee approved this research project.

Competing interests: None declared. 


\section{References}

1. World Health Organization. Physical status: the use and interpretation of anthropometry. WHO Technical Report Series 1995, 854. Geneva: World Health Organization, 1995.

2. Levy-Costa RB, Sichieri R, Pontes NS, Monteiro CA. Household food availability in Brazil: distribution and trends (1974-2003). Rev Saúde Pública 2005; 39: 530-40.

3. Dietz WH. Health consequences of obesity in youth: childhood predictors of adult disease. Pediatrics 1998; 101: 518-25.

4. Tucker LA, Bagwell M. Television viewing and obesity in adult females. Am J Public Health 1991; 81: 908-911.

5. Salmon J, Bauman A, Crawford D, Timperio A, Owen $\mathrm{N}$. The association between television viewing and overweight among Australian adults participating in varying levels of leisure-time physical activity. Int J Obes 2000; 24: 600-6.

6. Bowman SA. Television-viewing characteristics of adults: Correlations to eating practices and overweight and health status. Prev Chronic Dis 2006; 3(S2): 1-11.

7. Robinson TN. Does television cause childhood obesity? $J$ Am Med Assoc 1998; 279: 959-60.

8. Instituto Brasileiro de Geografia e Estatística. Pesquisa Nacional por Amostra de Domicílios (PNAD) 2007. Available in: [http://www.ibge.gov.br/home/estatistica/ populacao/trabalhoerendimento/pnad2007/default. shtm]. [Accessed on February 1st, 2009]

9. Bureau of Labor Statistics. American Time Use Survey Summary. United States Department of Labor. Available in: http://www.bls.gov/news.release/atus.nr0.htm. [Accessed on January 30th, 2009]

10. Albanes D, Jones DY, Micozzi MS, Mattson M. Associations between smoking and body weight in the US population: Analysis of NHANES 11. Am J Public Health 1987; 77: 439-44.

11. Molarius A, Seidell JC, Kuulasmaa K, Dobson AJ, Sans S. Smoking and relative body weight: an international perspective from the WHO MONICA Project. J Epidemiol Community Health 1997; 51: 252-60.

12. Huot I, Paradis G, Ledoux M. Quebec Heart Health Demonstration Project Research Group. Factors associated with overweight and obesity in Quebec adults. Int J Obes Relat Metab Disord 2004; 28: 766-74.

13. Troisi RJ, Heinold JW, Vokonas PS, Weiss ST. Cigarette smoking, dietary intake, and physical activity: effects on body. Am J Clin Nutr 1991; 53: 1104-11.

14. del Arbol, JL, Raya Munoz, J, Ojeda L, Lopez Cascales A, Rico Irles J, Miranda MT et al. Plasma concentrations of beta-endorphin in smokers who consume different numbers of cigarettes per day. Pharmacol Biochem Behav 2000; 67: 25-28.
15. Canoy D, Wareham N, Luben R, Welch A, Bingham S, Day $\mathrm{N}$ et al. Cigarette smoking and fat distribution in 21,828 British men and women: a population-based study. Obes Res 2005; 13: 1466-1475.

16. Centers for Disease Control and Prevention (CDC): Cigarette smoking among adults - United States, 2002. MMWR Morb Mortal Wkly Rep 2004; 53: 427.

17. Vassale C, Maffei S, Ndreu R, Mercuri A. Agerelated oxidative stress modulation by smoking habit and obesity. Clin Bioch 2009, doi:10.1016/j. clinbiochem.2008.11.017.

18. Peeters A, Barendregt JJ, Willekens F, Mackenbach JP, Al Mamun A, Bonneux L. NEDCOM, the Netherlands Epidemiology and Demography Compression of Morbidity Research Group. Obesity in adulthood and its consequences for life expectancy: a life-table analysis. Ann Intern Med 2003; 138: 24-32.

19. Healton CG, Vallone D, McCausland KL, Xiao H, Green MP. Smoking, obesity, and their co-occurrence in the United States: cross sectional analysis. $B M J 2006$; 333: 24-6.

20. Gutschoven, K. and J. Van den Bulck. Television viewing and smoking volume in adolescent smokers: a crosssectional study. Prev Med 2004; 39: 1093-8.

21. World Health Organization. Preventing and Managing the Global Epidemic. Report of a WHO Consultation on Obesity. Geneva: World Health Organization; 1998.

22. Delahanty JC, DiClemente CC, Havas S, Langenberg P. Smoking status and stages of change for dietary behaviors among WIC women. Am J Health Behav 2008; 32: 583-93.

23. Subar FA, Harlan CL, Mattson EM. Food and nutrient intake differences between smokers and non-smokers in the US. Am J Public Health 1990; 80: 1323-9.

24. Jeffery RW, French SA. Epidemic Obesity in United States: are Fast Foods and Television Viewing contributing? Am J Public Health 1998; 88: 277-80.

25. Vioque J, Torres A, Quiles J. Time spent watching television, sleep duration and obesity in adults living in Valencia, Spain. Int J Obes 2000; 24: 1683-8.

26. Cleland VJ, Schmidt MD, Dwyer T, Venn AJ. Television viewing and abdominal obesity in young adults: is the association mediated by food and beverage consumption during viewing time or reduced leisuretime physical activity? Am J Clin Nutr 2008; 87: 1148-55.

27. Dallongeville J, Marecaux N, Fruchart J-C, Amouyel P. Cigarette smoking is associated with unhealthy patterns of nutrient intake: a meta-analysis. J Nutr 1998; 128: $1450-1457$. 
28. Dyer AR, Elliott P, Stamler J, Chan Q, Ueshima H, Zhou BF et al. Dietary intake in male and female smokers, ex-smokers, and never smokers: The INTERMAP Study. $J$ Hum Hypertens 2003; 17: 641-654.

29. Castro JM, Taylor T. Smoking status relationships with the food and fluid intakes of free-living humans. Nutrition 2008; 24: 109-19.

30. French SA, Perry CL. Smoking among adolescent girls: prevalence and etiology. J Am Med Wom Assoc 1996; 51: 25-8.

31. Rigotti NA. Treatment options for the weight-conscious smoker. Arch Intern Med 1999; 159: 1169-71.

32. French SA, Jeffery RW. Weight concerns and smoking: a literature review. Ann Behav Med 1995; 17: 234-44.

33. Marques-Vidal P, Bochud M, Mooser V, Paccaud F, Waeber G, Vollenweider P. Prevalence of obesity and abdominal obesity in the Lausanne population. BMC Public Health 2008; 8: 330 doi:10.1186/1471-2458-8-330.
34. Pasquali R, Vicennati V. Activity of the hypothalamicpituitary-adrenal axis in different obesity phenotypes. Int J Obes Relat Metab Disord 2000; 24(S): S47-9.

35. Cryer PE, Haymond MW, Santiago JV, Shah SD. Norepinephrine and epinephrine release and adrenergic mediation of smoking-associated hemodynamic and metabolic events. N Engl J Med 1976; 295(11): 573-7.

36. Steptoe A and Ussher M. Smoking, cortisol and nicotine. Int J Psychophysiol 2006; 59 (3): 228-35.

37. Carney RM, Goldberg AP. Weight gain after cessation of cigarette smoking. A possible role for adipose-tissue lipoprotein lipase. N Engl J Med 1984; 310: 6146.

38. Tanko LB, Christiansen C. An update on the antiestrogenic effect of smoking: a literature review with implications for researchers and practitioners. Menopause 2004; 11(1): 104-9.

Received: 25/08/11

Final version: 06/03/12

Approved: 23/05/12 